\title{
Kontroversi Dasar Hukum Sidang Istimewa MPR dan Maklumat Presiden 23 Juli 2001 (Tinjauan Yuridis Ketatanegaraan)
}

\author{
Ni’matul Huda
}

\begin{abstract}
A number of controversial policies taken by President Abdurrahman Wahid, for example, conceming the discharge of the head of Indonesian police (Kapolri), have brought about . strong reaction and critic from Legislative Assembly /People's Consultative Council. The conflict between two institutions had become worse when President Wahid issued a decree on July 23, 2001 which, eventually, made him loose his power (mandate) in the special session of People Consultative Council. The special session or President's policy to fire Kapolri, if examined from the constitutional law point of view, caused polemic among society, especially in respect to the basis of law employed by each party. This incident showed how vulnerable the system established by constitution is, because some important problems in the constitutional law have not been set up clearly and explicitly in the constitution. Therefore, the constitutional reformation is an urgent agenda which must be finished as soon as possible.
\end{abstract}

\section{Pendahuluan}

Sebelum kekuasaan (mandat) Presiden Abdurrahman Wahid dicabut oleh MPR melalui Sidang Istimewa MPR 23 Juli 2001, Presiden seringkali menggulirkan wacana yang bernada 'ancaman' akan mengeluarkan Dekrit Presiden kalau kompromi politik tidak tercapai antara Presiden dengan DPR/MPR. Ancaman itu muncul karena posisi Presiden yang terus menerus disudutkan dengan berbagai persoalan, yang entry point-nya dimulai dari kesimpulan Pansus Kasus Bulog dan Kasus Brunei, yang "mengindikasikan keterlibatan" Presiden dalam Kasus Bulog dan
Kasus Brunei. Atas hasil Pansus itu kemudian DPR mengajukan memorandum pertama (I), memorandum kedua dan berujung di SI MPR. Anehnya, isi (substansi) memorandum pertama dan kedua tidak ada keterkaitan persoalan, memorandum pertama tentang dugaan keterlibatan Presiden pada "Kasus Bulog dan Kasus Brunei", sedangkan memorandum kedua berisi tentang beberapa tindakan Presiden yang dipandang melanggar Haluan Negara.

Atas dasar permintaan DPR kepada MPR untuk segera menggelar Sidang Istimewa (SI) untuk meminta pertanggungjawaban 
Presiden, MPR menetapkan jadwal SI akan dilaksanakan pada tanggal 1 Agustus 2001. Sesuai aturan main yang ada (TAP MPR No. II/MPR/1999 sebagaimana yang sudah diubah melalui TAP MPR No. II/MPR/2000 tentang Peraturan Tata Tertib MPR) Pasal 33 ayat (3), Badan Pekerja MPR menyelenggarakan rapat sekurang-kurangnya dua bulan, setelah itu baru dilaksanakan SI. ${ }^{1}$

Ternyata realitas politik berbicara lain, SI yang dimaksudkan sebagai jalan keluar (solusi) atas konflik yang kian menajam antara Presiden dengan DPR ternyata justru memperuncing keadaan hubungan kelembagaan Presiden dan DPR. Akhirnya MPR justru mengajukan jadwal SI pada tanggal 23 Juli 2001. 'Percepatan SI' dilakukan MPR dengan alasan adanya perkembangan situasi dan kondisi yang semakin memburuk, yang mengancam keselamatan dan integritas bangsa dan negara. Pandangan MPR ini dipertegas lagi dengan pemberhentian Kapolri Jenderal Surojo Bimantoro dan pengangkatan Wakapolri Chaerudin Ismail menjadi Pemangku Pelaksana Tugas (PIt) Kapolri.
Tindakan Presiden tersebut dinilai oleh MPR bertentangan dengan Pasal 7 ayat (3) TAP MPR No. VII/MPR/2000 tentang Pemisahan Tentara Nasional Indonesia. ${ }^{2}$

Melalui SI MPR 23 Juli 2001, satu lagi peristiwa yang sangat penting dalam sejarah ketatanegaraan Republik Indonesia berlangsung di gedung MPR, yakni pencabutan mandat Presiden Abdurrahman Wahid (in absensia). Pencabutan mandat Presiden oleh MPR dipercepat prosesnya karena ternyata Presiden pada tanggal 23 Juli 2001 dini hari (01.05 WIB) mengumumkan Maklumat Presiden, yang kemudian lebih dikenal dengan Dekrit Presiden. Atas realitas politik tersebut, di masyarakat timbul sikap pro dan kontra terhadap putusan MPR yang mencabut mandat Presiden Abdurrahman Wahid.

Dari paparan di atas muncul persoalan, ditinjau dari perspektif Hukum Tata Negara menarik untuk dicermati. Pertama, apakah tindakan Presiden memberhentikan Kapolri dan. mengangkat Wakapolri sebagai Pelaksana Tugas Kapolri bertentangan dengan konstitusi? Kedua, apakah 'percepatan' SI MPR sah di

'Menurut Harus Alrasid (penasehat Presiden bidang hukum tata negara), pertanggungjawaban Presiden tidak diatur dalam UUD 1945 tetapi hanya diatur di dalam Penjelasan UUD 1945 dan TAP MPR sehingga dasar hukumnya tidak kuat. Sementara itu, pada sisi lain, MPR menganggap SI itu sah karena bersumber dari Penjelasan UUD 1945 dan Ketetapan MPR No. III/MPR/1978 jo TAP MPR No. II/MPR/2000

${ }^{2}$ Jabatan Wakapolri muncul melalui Keputusan Presiden (Keppres) No. 77 Tahun 2001 tentang Pengesahan Jabatan Wakapolri, tertanggal 21 Juni 2001. Keppres ini dianggap bertentangan dengan Keppres No. 54 Tahun 2001 tentang Organisasi dan Tata Kerja Polri, tanggal 25 April 2001. Keppres No. 54 Tahun 2001 menegaskan bahwa jabatan kedua setelah Kapolri adalah Sekjen Polri. Mahkamah Agung tanggal 31 Juli 2001 telah mengeluarkan putusan menerima keberatan atas permohonan hak uji materiil (judicial review) yang dimajukan oleh Tim Pembela Konstitusi yang dipimpin Adnan Buyung Nasution terhadap semua Keppres yang terkait dengan pemberhentian Kapolri Bimantoro dan pengangkatan Wakapolri Chaerudin Ismail, yakni Keppres No. 77 Tahun 2001 tentang Pengesahan jabatan Wakapolri, Keppres. No. 40 Tahun 2001 tentang Penonaktifan Kapolri Jenderal Surojo Bimantoro dan Keppres No. 41 Tahun 2001 tentang Pengangkatan Wakaporri Irjen Polisi Chaerudin ismail menjadi Pelaksana Tugas (PIt) Kapolri. 
mata hukum yang berlaku? Ketiga, apakah Presiden bewwenang mengeluarkan Maklumat (Dekrit)?

\section{Pengangkatan dan Pemberhentian Kapolri}

Salah satu produk hukum yang dilahirkan oleh MPR dalam Sidang Tahunan MPR RI 718 Agustus 2000 adalah Ketetapan MPR No. VI/MPR/2000 tentang Pemisahan Tentara Nasional Indonesia dan Kepolisian Negara Republik Indonesia. Hal ini dilakukan sebagai realisasi dari salah satu tuntutan reformasi yang dikumandangkan oleh rakyat Indonesia yang dimotori oleh mahasiswa pada tahun 1998. Bahwa dengan dilakukannya penggabungan Angkatan Darat, Angkatan Laut, Angkatan Udara dan Kepolisian Negara RI dalam Angkatan Bersenjata RI (ABRI) telah terjadi kerancuan dan tumpang tindih antara peran dan fungsi Tentara Nasional Indonesia (TNI) sebagai kekuatan pertahanan negara dengan peran dan tugas Kepolisian Negara RI sebagai kekuatan keamanan dan ketertiban masyarakat. Di samping itu, peran sosial politik dalam dwifungsi ABRI telah menyebabkan terjadinya penyimpangan peran dan fungsi TNI dan Kepolisian Negara RI yang berakibat tidak berkembangnya sendi-sendi demokrasi dalam kehidupan berbangsa bernegara dan bermasyarakat. Untuk itu perlu dilakukan reposisi dan restrukturisasi Angkatan Bersenjata Rl.

Seiring dengan proses demokratisasi dan globalisasi, serta menghadapi tuntutan masa depan, perlu peningkatan kinerja dan profesionalisme aparat pertahanan dan aparat keamanan melalui penataan kembali peran TNI dan peran Kepolisian Negara RI. Setelah dilakukan pemisahan secara kelembagaan yang setara antara TNI dan Kepolisian Negara RI melalui TAP MPR No. VI/MPR/2000, maka sebagai penegasan terhadap peran TNI dan peran Kepolisian Negara RI, telah dikeluarkan Ketetapan MPR No. VII/MPR/2000.

Melalui Ketetapan MPR No. VII/MPR/2000 kedudukan Tentara Nasional Indonesia dan Kepolisian Negara RI ditegaskan berada di bawah Presiden (Pasal 3 ayat (2) dan Pasal 7 ayat (2)). Tentara Nasional Indonesia dipimpin oleh seorang Panglima yang diangkat dan diberhentikan oleh Presiden setelah mendapat persetujuan DPR (Pasal 3 ayat (3)). Begitu pun dengan Kepolisian Negara RI, Kepolisian Negara RI dipimpin oleh Kepala Kepolisian Negara RI yang diangkat dan diberhentikan oleh Presiden dengan persetujuan DPR (Pasal. 7 ayat (3)). Pasal 11 Ketetapan ini memerintahkan pengaturan lebih lanjut ketentuan sebagaimana dimaksud dalam ketetapan ini diatur dengan undang-undang.

Sebagaimana diketahui, bahwa sampai hari ini undang-undang yang diperintahkan oleh Pasal 11 TAP MPR No. VII/MPR/2000 belum lahir. Sementara itu, undang-undang yang ada mengatur tentang Kepolisian Negara RI UU No. 28 Tahun 1997 belum dicabut dan masih dinyatakan berlaku. Timbul pertanyaan, apakah UU No. 28 Tahun 1997 masih dapat dijadikan rujukan yuridis operasional Kepolisian Negara RI dan apakah materi muatannya sesuai dengan semangat Ketetapan MPR No. VII/MPR/2000 tersebut? Dapatkah untuk sementara waktu UU No. 28 Tahun 1997 dipergunakan sebagai landasan yuridis operasional peran Kepolisian Negara RI sebelum adanya undang-undang pengganti sesuai yang dikehendaki oleh Pasal 11 TAP MPR No. VIII MPR/2000? Permasalahan ini muncul karena realitanya menimbulkan polemik di masyarakat 
an bahkan diantara Presiden dan DPR enimbulkan perbedaan penafsiran, shingga butuh kejelasan status hukum dari U tersebut.

$\therefore$ Salah satu persoalan yang dijadikan alasan APR untuk meminta pertanggungjawaban residen Abdurrahman. Wahid adalah pemberentian Rusdihardjo dari jabatan Kapolri tanpa ersetujuan DPR (tanggal 18 September 2000; jengangkat dan sekaligus menonaktifkan enderal Surojo Bimantoro sebagai Kapolri anggal 1 Juni 2000), dan terakhir memberentikannya dari jabatan Kapolri tanpa peretujuan DPR (tanggal 1 Juli 2000). Kemudi$\mathrm{n}$ disusul dengan . tindakan lanjutan berupa engangkatan Jenderal Chaerudin Ismail seragai Pemangku Sementara Jabatan Kapolri. 4tas tindakan tersebut Presiden dinilai telah 1elanggar TAP MPR No.VII/MPR/2000. 'ersoalannya adalah, apakah TAP MPR No. /II/MPR/2000 itu sudah efektif pemberlauannya mengingat instrumen pelaksanaannya ang berupa undang-undang belum ada. Japatkah Presiden bertindak dengan bersandar sada UU No. 28 Tahun 1997.

Menurut Suwoto Mulyosudarmo, tindakan residen memberhentikan Kapolri masih bisa Aibenarkan sebab TAP MPR itu masih belum nemiliki instrumen pelaksanaan berupa indang-undang. ${ }^{3}$ Sependapat dengan Suwoto $\checkmark$, jika aturan pelaksanaannya belum ada dan undang-undang yang lama belum dicabut, naka tindakan Presiden dalam nemberhentikan átaúpun mèngangkat Kapolri ;elama ini dapat dibenarkan karèna TAP MPR vo. VII/MPR/2000 tidak memberikan Jenegasan pencabutan terhadap UU No. 28
Tahun 1997.

Menurut ketentuan Pasal 11 UU No. 28 Tahun 1997, Kepala Kepolisian RI diangkat dan diberhentikan oleh Presiden (ayat (1)); Pengangkatan dan pemberhentian jabatan selain yang dimaksud pada ayat (1) diatur.lebih lanjut oleh Panglima, atas usul Kepala Kepolisian RI (ayat 3). Ketentuan tersebut jelas mengatur bahwa untuk pengangkatan dan pemberhentian Kapolri menjadi wewenang Presiden, tanpa harus sepersetujuan DPR: Ketentuan inilah yang mungkin dipakai oleh Presiden sebagai șandaran yuridis didalam mengangkat dan memberhentikan Kapolri.

Secara substantif materi muatan UU No. 28 Tahun 1997 khususnya yang mengatur masalah pengangkatan dan pemberhentian Kapolri sudah tidak sesuai dengan isi TAP MPR No. VII/MPR/2000. Kewenangan Presiden dalam pengangkatan dan pemberhentian Kapolri tidak dapat lagi sepenuhnya dimiliki oleh Presiden karena adanya keharusan persetujuan dari DPR. Untuk itu, DPR dan Presiden harus segera melengkapi perintah TAP MPR No. VII/MPR/2000 dengan membuat undang-undang yang baru, agar supaya kasus yang sama tidak berulang dan ada pijakan yang jelas bagi Presiden dalam melaksanakan TAP tersebut.

\section{Kontroversi, SI MPR (yang dipercepat)}

$\therefore$ Penolakan'Presiden untuk memberikan pèrtanggungjawaban dan juga hadir di Sidang Istimewa MPR yang semula dijadwalkan 'akan berlangsung 1 Agustus 2001, yang kemudian' dimajukan tanggal 23 Juli 2001, bermula da-

${ }^{3}$ Harian Jawa Pos. Rabu. Tanggal 4 Juli 2001. 
ri perbedaan sudut pandang antara Presiden dan MPR dalam penerapan dasar yuridisnya. MPR memandang dirinya sebagai lembaga tertinggi negara memiliki kewenangan untuk menggelar Sidang Istimewa karena adanya permintaan dari DPR atas "Kasus Bulog dan Kasus Brunei", yang akhimya muncul Memorandum I dan II dari DPR dan berujung pada permintaan SI kepada MPR.

Pada sisi lain, Sidang Istimewa MPR menurut pendapat Presiden ilegal karena sandaran yuridisnya tidak mengacu ke UUD 1945 (Batang Tubuh UUD) tetapi pada Penjelasan UUD 1945 dan TAP MPR. ${ }^{4}$ Di samping itu, sistem yang dianut oleh UUD 1945 tidak mengenal pertanggungjawaban Presiden sebagaimana lazim berlangsung dalam sistem parlementer. Sistem yang dianut di Indonesia (UUD 1945) adalah Presidensiil. Pertanggungjawaban hanya akan diberikan diakhir masa jabatan, yakni tahun 2004, dan bukan di tengah perjalanan masa jabatan. Itu pun bersifat intern dalam kerangka hubungan antara si pemberi mandat (mandat) dan si penerima mandat (mandataris).

Pada sisi lain, MPR berpandangan bahwa Sl itu legal karena dasamya tegas diatur di dalam Ketetapan MPR No. III/MPR/1978 dan
Ketetapan MPR No. II/MPR/2000. Presider harus hadir dan memberikar pertanggungjawaban:

Sedangkan pelaksanaan SI MPR yyanc dipercepat' menurut MPR didasarkan pada pertimbangan keadaan atau situasi negara yang semakin memburuk, sehingga MPR merasa perlu untuk segera mengantisipast keadaan, karena Presiden Abdurrahman Wahid sudah mengumumkan akar. mengeluarkan dekrit tanggal 20 Juli 2001 yang akan membekukan MPR dan parlemen. Fenomena politik yang demikian inilah yang dijadikan dasar oleh MPR untuk bertindak cepat dengan memajukan jadwal SI pada tanggal 23 Juli 2001.

Apabila dikaji dari perspektif yuridis penyelenggaraan SI MPR, nampaknya memang timbul kerancuan dan benturan yuridis :antara satu aturan dengan aturan yang lain. Pertama, antara Ketetapan MPRS No. XX MPRS/1966 dengan Ketetapan MPR No. III/ MPR/2000 tentang sumber hukum dan tata urutan peraturan perundang-undangan. $\mathrm{Di}$ dalam TAP MPRS No. XXMPRS/1966 secara tersirat maupun tersurat menggambarkan bahwa UUD 1945 terdiri dari Pembukaan, Batang Tubuh, dan Penjelasan UUD 1945

\footnotetext{
${ }^{4}$ Menurut Harun Alrasid, TAP MPR merupakan barang 'haram' karena UUD 1945 tidak mengenal produk hukum yang bernama ketetapan. Moh. Kusnardi dan Hermaily Ibrahim dalam bukunya Pengantar Hukum Tata Negara.Indonesia, Penerbit Pusat Studi Hukum Tata Negara FH Ul, Cetakan Ketujuh, Jakarta, 1988, Hlm. 46, mengatakan: "Istilah ketetapan dalam Ketetapan MPRS/MPR sebenarnya tidak ada dalam UndangUndang Dasar 1945. Istilah ini mungkin diambil MPRS pada sidang-sidangnya yang pertama, dari bunyi Pasal 3 UUD 1945 dimana terdapat sumber hukum, karena UUD 1945 menyebutkan bahwa MPR berwenang menetapkan UUD, Garis-garis Besar Haluan Negara (Pasal 3), memilih Presiden dan Wakil Presiden (Pasal 6 ayat (2)), dan merubah UUD (Pasal 37)." Ketetapan MPRS pada saat ini masih merupakan sumber hukum, karena ada beberapa Ketetapan MPRS yang masih dinyatakan berlaku oleh Ketetapan MPR No. VIMPR/ 1973.
} 
yang merupakan penjelasan yang otentik. Dengan menyebutnya sebagai penjelasan otentik, —dalam arti sebagai unsur UUD 1945, - maka sudah tidak dapat lagi dipersoalkan atau disangsikan hubungan antara penjelasan dengan batang tubuh UUD 1945. Apalagi setelah melalui Dekrit Presiden 5 Juli 1959 di mana dikembali ke UUD 1945 dan dimuat dalam Lembaran Negara No. 75 Tahun 1959 serta dinyatakannya Penjelasan UUD 1945 itu sebagai Penjelasan otentik oleh Ketetapan MPRS No. XXJMPRS/1966, maka jelaslah bahwa Penjelasan UUD 1945 merupakan bagian resmi dan tak terpisahkan dari UUD 1945.5

Akan tetapi, saat ini Ketetapan MPRS No. XX/MPRS/1966 tersebut telah dicabut keberlakuannya oleh Ketetapan MPR No. III/ MPR/2000 tentang Sumber Hukum dan Tata Urutan Peraturan Perundang-undangan. Ketetapan MPR No. III/MPR/2000 Pasal 3 ayat (1) menyatakan, "Undang-Undang Dasar 1945 'merupakan hukum dasar tertulis Negara Republik Indonesia, memuat dasar dan garis besar hukum dalam penyelenggaraan negara."
Persoalannya adalah, apakah menurut TAP MPR No. III/MPR/2000 Penjelasan UUD 1945 juga menjadi bagian yang tak terpisahkan dari batang tubuh UUD 1945 dan sebagai penjelasan otentik? Hal ini tidak ada penjelasan lebih lanjut sebagaimana yang tertuang di dalam TAP MPRS No. XX/MPRS/1966, sehingga ada celah (peluang) untuk ditafsirkan secara luas (debatebel). Kalau Penjelasan UUD 1945 "dianggap" masih menjadi penjelasan otentik dari batang tubuh UUD 1945, apakah dengan adanya perubahan pertama dan perubahan kedua UUD 1945, Penjelasan UUD 1945 masih relevan dan sinkron dengan batang tubuh UUD 1945 (baru)? Apabila Penjelasan tidak lagi menjadi satu kesatuan dengan batang tubuh dan tidak lagi menjadi penjelasan otentik dari UUD 1945, dari mana sandaran yuridis pertanggungjawaban Presiden diambil? Bukankah penegasan kedudukan Presiden sebagai mandataris Majelis yang bertindak dan bertanggung jawab kepada Majelis diatur di dalam Penjelasan UUD 1945. ${ }^{6}$

SLihat J.C.T. Simorangkir. 1984. Penetapan UUD Dilihat Dari Segillmu Hukum Tata Negara Indonesia. Jakarta: Gunung Agung. Hlm. 25. Lihat juga dalam Ni'matul Huda. 1999. Hukum Tata Negara, Kajian Teoritis dan Yuridis Terhadap Konstitusi Indonesia. Yogyakarta: Pusat Studi Hukum Fakultas Hukum UII kerjasama dengan Gama Media. Hlm. 43-45.

${ }^{6}$ Menurut Jimly Asshiddiqie, setelah diadakan Perubahan Pertama dan Kedua UUD 1945, materi Penjelasan UUD 1945 tidak mungkin lagi dipertahankan. Banyak perubahan yang tercakup dalam kedua.

Perubahan itu yang sudah tidak cocok lagi dengan isi Penjelasan. Di samping itu, banyak pula ahli hukum yang mempersoalkan mengenai keabsahan Penjelasan UUD itu sendiri sebagai bagian dari dokumen konstitusi yang mengikat. Lihat Jimly Asshiddiqie, "Konsolidasi Materi UUD RI", makalah yang disampaikan dalam kuliah perdana Program Magister (S2) IImu Hukum UII tanggal 13 September 2001, HIm. 4. Lihat juga Bagir Manan, Menyongsong Fajar Otonomi Daerah, Pusat Studi Hukum FH Ull.Yogyakarta. 2001.HIm. 7. 
Dapatkah MPR membuat 'lompatan' dasar yuridis pertanggungjawaban Presiden langsung kepada Ketetapan MPR No. III/MPR/ 1978 jo Ketetapan, MPR No. II/MPR/2000? Persoalan ini tentu butuh kehati-hatian dan kecermatan dalam penerapan hukumnya, méskipun MPR sebagai lembaga tertinggi negara dapat menafsirkan seolah-olah dapat melakukan apa pun - seperti yang selama ini diyàkininya- karena kedaulatan rakyat dilakukan sepenuhnya oleh MPR (Pasal 1 ayat (2) UUD 1945). Kedua, 'Percepatan' SI MPR yang didasarkan pada tindakan Presiden melantik Wakapolri Komisaris Jenderal Chaerudin Ismail sebagai Pemangku. Sementara Jabatan Kapolri dan menaikkan pangkatnya menjadi jenderal, dipandang Presiden telah melanggar Ketetapan MPR No. VIIIMPR/2000. Dari kacamata yuridis tindakan MPR yang menyelenggarakan SI atas dasar tuduhan Presiden melanggar TAP MPR No. VII/MPR/2000 tidaklah sepenuhnya benar. Pertama, Jenderal Chaerudin tidak diangkat sebagai Kapolri, tetapi sebagai Pemangku Sementara Jabatan Kapolri, sehingga tidak perlu meminta persetujuan DPR. Sedangkan ketentuan di dalam Pasal 7 ayat (3) TAP MPR No. VII/MPR/2000 yang mensyaratkan adanya persetujuan dari DPR untuk pengangkatan dan pemberhentian Kapolri. Dilihat dari istilah "sementara" sụdah dapat diketahui bahwa. masa pemangkuan sementara jabatan Kapolri relatif singkat. Dengan kata lain, tidaklah terlalu lama waktunya, yakni.selama yang digantikan berhalangan, bukan menggantikan secara definitif.

Kedua, Apabila tindakan Preśiden itu dipandang beitentangan dengan TAP MPR No. VII/MPR/2000, apakah tepat MPR yang langsung memberikan reaksi dengan menggelar
SI? Adakah ketentuan yang mengatur tentang SI tanpa melalui mekanisme memorandum DPR? Bukankah seharusnya.DPR yang memberi peringatan kepada Presiden kalau tindakan itu dipandang melanggar TAP MPR, karena kewenangan untuk memberikan persetujuan dalam pengangkatan dan pemberhentian Kapolri ada pada DPR, dan bukan di tangan MPR. Tindakan MPR justru dipandang berlebihan bahkan melanggar konstitusi (TAP MPR No. III/MPR/1978 jo TAP MPR No. II/ MPR/ 2000). Di dalam Tap MPR No. I//MPR/ 2000 Pasal 50 ayat (3) ditentukan bahwa "Sidang Istimewa Majelis adalah:

(a) sidang yang diselenggarakan Majelis selain Sidang Umum dan Sidang Tahunan Majelis;

(b) sidang yang diselenggarakan Majelis atas permintaan Dewan Perwakilan Rakyat untuk meminta dan menilai pertanggungjawaban Presiden atas pelaksanaan putusan Majelis;

(c) sidang yang diselenggarakan Majelis untuk mengisi lowongan jabatan Presiden dan/atau Wakil Presiden apabila Presiden dan/atau Wakil Presiden berhalangan tetap.

Kemudian di dalam Pasal 33 ayat (3) TAP MPR No. II/MPR/2000 ditegaskan pula bahwa "Dalam hal menghadapi Sidang Istimewa Majelis, Badan Pekerja Majelis menyelenggarakan rapat sekurang-kurangnya dua bulan sebelum Sidang Istimewa Majelis diselenggarakan, kecuali Sidang Istimewa Majelis untuk mengisi lowongan Presiden dan Wakil Presiden yang berhalangan tetap." Sehingga andai pun untuk tindakan Presiden mengangkat Chaerudin menjadi Pemangku Sementara Jabatan Kapolri dipandang bersalah, maka Sidang Istimewa 'baru dapat 
dilaksanakan dua bulan ke depan, yakni 21 September 2001.' Berdasarkan hal-hal di atas, SI yang direncanakan dimulai Senin 23 Juli 2001 tidak memenuhi ketentuanTata Tertib MPR sendiri, sehingga melanggar TAP MPR No. II/MPR/1999 yang telah diubah dengan TAP MPR No. II/MPR/2000.

Kalau demikian halnya, apa dasar hukum 'percepatan' SI MPR? Adakah pengaturannya di dalam konstitusi (UUD 1945)? Sepanjang pengetahuan penulis, tidak ada aturan yang mengatur tentang 'percepatan' SI (Lihat TAP MPR No. II/MPR/2000). Menurut saran Badan Pekerja MPR sebagaimana yang dituangkan dalam Keputusan BP No. 3/2001, alasan dipercepatnya SI MPR adalah adanya penilaian telah terjadi perkembangan situasi dan kondisi yang semakin memburuk, yang mengancam keselamatan dan integritas bangsa dan negara, sehingga memaksa MPR harus segera mengambil tindakan secepatnya demi keselamatan bangsa dan negara. Adakah kewenangan konstitusional bagi MPR untuk menyatakan keadaan bahaya/darurat șehingga MPR sah untuk bertindak menyimpangi ketentuan di dalam TAP MPR No.III/MPR/1978 jo TAP MPR No. II/MPR/2000.

Apabila dicermati isi UUD 1945, Pasal. 12 menyatakan bahwa "Presiden menyatakan keadaan bahaya, syarat-syarat dan akibat keadaan bahaya ditetapkan dengan Undang- undang". Dari ketentuan tersebut nampak jelas bahwa yang berhak dan berwenang menyatakan keadaan bahaya adaląh Presiden. Lantas dari mana tindakan MPR bersandar (berpijak)?

Menurut Jimly Asshiddiqie, jika kepentingan umum menghendaki dipercepatnya SI MPR, maka MPR dapat menyimpangi (mengesampingkan) peraturan Tatib yang mengatur dan mengikat mereka sendiri. Yang secara langsung dapat dijadikan dasar untuk mengabaikan Peraturan Tata Tertib yang mengharuskan persiapan selama 2 bulan itu adalah "keadaan darurat" (noodstand) yang dalam doktrin ilmu hukum diakui sebagai dasar hukum untuk melakukan tindakantindakan hukum yang bersifat darurat pula. Keadaan darurat yang menyangkut keadaan kegentingan yang memaksa bagi MPR untuk dalam waktu yang secepat-cepatnya melakukan langkah konstitusional guna menyelamatkan negara dari ancaman bahaya. Keadaan yang bersifat darurat itu jelas menyangkut kepentingan umum seluruh rakyat yang tidak dapat ditawar-tawar untuk segera diatasi oleh MPR yang merupakan penjelmaan seluruh rakyat, pelaku sepenuhnya kedaulatan rakyat Indonesia, dan sebagai lembaga tertinggi negara yang kekuasaannya "tidak terbatas". ${ }^{8}$

Lebih lanjut Jimly mengakui, bahwa UUD dan UU No. 23 Tahun 1959 memang memberi-

${ }^{7}$ Sesuai isi surat Presiden kepada MPR yang menolak memberikan pertanggungjawabannya dalam SI, Surat R-55/Pres $N I / 12000$, Presiden memandang waktu dua bulan yang diberikan sesuai dengan ketentuan di dalam TAP MPR No. II/MPR/2000, akan memberikan waktu yang cukup dan wajar kepada Presiden, bilamana perlu menghadirinya untuk menyiapkan uraian yang diperlukan pada SI tersebut. Hal mana tidak mungkin bila masa persidangan bagi Presiden itu hanya sehari menjelang pelaksanaan Sl.

${ }^{8}$ Jimly Asshiddiqie. "Pemberhentian Presiden Melalui SI MPR yang Dipercepat." Makalah yang dipresentasikan di hadapan Fraksi PDIP. tanpa tanggal dan tahun. HIm. 3. 
kan "fasilitas legal" kepada Presiden untuk memberlakukan keadaan darurat, bukan kepada MPR. Akan tetapi, MPR sebagai lembaga tertinggi negara, penjelmaan seluruh rakyat, pelaku sepenuhnya kedaulatan rakyat, dan sekaligus puncak kekuasaan legislatif dalam sistem hukum dan konstitusi negara, darimana mandat yang diterima oleh Presiden untuk memiliki kewenangan memberlakukan keadaan darurat itu berasal, tentulah juga berwenang menafsirkan timbulnya keadaan yang nyata-nyata menjurus kepada keadaan darurat itu. Jika keadaan darurat itu dinilai jüstru akan terjadi karena ucapan, tindakan ataupun kebijakan yang sengaja dilakukan oleh Presiden, sudah tentu bukan saja MPR berwenang, tetapi bahkan wajib mengambil langkah-langkah konstitusional yang segera untuk mencegah terjadinya keadaan darurat itu. ${ }^{9}$

Menurut Ignas Kleden, ${ }^{10}$ keadaan sekarang ini bukannya menjadi lebih normal, melainkan menjadi lebih rumit, karena sekarang ada preseden baru bahwa dengan sistem dan mekanisme politik yang ada; DPR dapat mengusulkan Sidang Istimewa MPR, dan seterusnya MPR dapat memanggil Sidang Istimewa setiap saat, dan kekuasaan Presiden segera berada di ujung tanduk. Maka stabilitas pemerintahan justru menjadi penuh risiko karena adanya kesempatan yang diberikan kepada badan legislatif dan MPR untuk menjatuhkan Presiden di tengah jalan. Masyarakat semua tahu alasan "negara ada dalam keadaan bahaya" selalu dapat direkayasa, dan begitu sebagian besar Anggota
MPR menyetujuinya, tamatlah riwayat Presiden yang mana pun.

Ahli ilmu politik LIPI, Mochtar Pabotinggi berulang kali menekankan bahwa politik Indonesia dan peralihan kekuasaan politik tidak bisa terus menerus didasarkan pada psikologi keadaan darurat atau political emergency psychology. Pada masa pemerintahan Soeharto, dialami bahwa pihak eksekutif atau Presiden Soeharto amat pandai memainkan keadaan darurat ini untuk melanggengkan kekuasaannya. Godaan yang dihadapi sekarang adalah bahwa legislatif dan MPR dapat terjebak ke dalam kondisi yang sama untuk memainkan juga alasan 'keadaan darurat' bukan untuk melanggengkan kekuasaan (seperti yang dilakukan Soeharto), tetapi untuk. mengakhiri kekuasaan eksekutif, yang barangkali tidak menguntungkan kepentingan orang-orang dalam lembaga legislatif sendiri.

Lebih lanjut Kleden mengatakan, persoalan yang amat serius sekarang ini ialah: bagaimana keputusan MPR dapat diawasi? Pada titik ini rakyat dihadapkan pada suatu masalah fundamental dalam demokrasi yaitu akuntabilitas dan rasionalitas politik dari MPR sendiri. Apa yang terjadi kalau sebagian besar anggota MPR memberikan suatu keputusan yang terangterangan tidak menguntungkan kepentingan nasional, mengabaikan keadilan, mengganggu stabilitas politik, atau bahkan bertentangan dengan undang-undang dasar? Siapa yang dapat mengontrol dan, kalau boleh, mencegah semua ini? Maka perlu dicari jalan bahwa keputusan MPR pun memerlukan suatu mekanisme untuk akuntabilitasnya.

${ }^{9}$ Ibid. HIm. 7.

${ }^{10}$ Ignas Kleden. "Kepemimpinan Nasional dan Krisis Politik". Harian Kompas. Tanggal 30 Juli 2001. HIm. 4. 
Pertanyaan yang menarik dilontarkan oleh Kleden ialah, apakah alasan kinerja dan prestasi kerja dapat menjadi dasar untuk menjatuhkan seorang Presiden? Apakah seorang Presiden yang mengambil menterimenteri yang tidak kompeten dapat diberhentikan? Dalam hal ini competence dan performance haruslah ditanggung sebagai risiko dari pemilihan Presiden. Orang-orang yang memilih seorang tokoh menjadi Presiden mereka sebaiknya bersiap bahwa Presiden mereka barangkali akan gagal dan kegagalan ini harus mereka tanggung, tanpa harus memberhentikan Presidennya di tengah jalan. Hal ini kurang lebih sama dengan sikap kita terhadap badan legislatif, di mana kita juga: tidak dapat membubarkan DPR dan MPR karena mereka tidak bekerja maksimal, meskipun mereka dibayar mahal dengan uang negara. Mendapatkan anggota DPR yang rendah kinerjanya, adalah" risiko yang harus ditanggung oleh parapemilihnya, tanpa harus membubarkan DPR. ${ }^{12}$

Suwoto Mulyosudarmo berpendapat bahwa ada proses hukum yang cacat dalam pemberhentian Gus Dur oleh MPR. Cacat itu bermula dari Sidang Páripurna MPR yang dilangsungkan pada hari Sabtu, 21 Juli. Memang, pada Jumat malam, 20 Juli, Pimpinan MPR menggelar rapat. Rapat itulah yang memutuskan untuk menggelar SI MPR pada 23 Juli 2001. Ketua MPR Amien Rais menyebutkan bahwa Sidang Paripurna pada
Sabtu itumerupakan bagian yang tak terpisahkan dari SI MPR. Tapi, Suwoto tidak tahu persis, Sidang Paripurna itu sidang Istimewa atau bukan. ${ }^{13}$

Menurut Moh. Mahfud MD, percepatan SI kemarin setidaknya mengalami tiga problem yuridis. Pertama, diadakan SI dikarenakan Presiden mengangkat Kapoli atau Pemangku Sementara Jabatan Kapolri tanpa konsultasi dengan DPR. Padahal untuk melaksanakan SI karena terjadinya pelanggaran tersebut harus melalui proses memo satu (I) dan memo dua (II). Namun SI karena kasus Kapolri ini belum ada peringatan tetapi langsung SI. Kedua, masalah sidang paripurna. Dalam TAP MPR No. II/MPR/1999 Sidang Paripurna merupakan bagian dari Sidang Umum, Sidang Tahunan atau Sidang Istimewa. Dalam ketiga sidang tersebut caranya ada rapat paripurna, ada rapat komisi. Saat ini rapat paripurnanya a da, tetapi SI-nya belum. Problem ketiga, agak sulit bagi MPR untuk mengambil keputusan, karena berdasarkan Pasal 87 TAP MPR No. I//MPR/1999 disebutkan untuk memutuskan sesuatu semua fraksi harus hädir. Padahal sekarang ada dua fraksi yang tidak hadir. Bisa tidak sidang seperti itu mengambil keputusan yang fundamental. ${ }^{14}$

Ketidakhadiran dan penolakan Presiden RI K.H. Abdurrahman Wahid untuk memberikan pertanggungjawaban dalam Sidang Istimewa MPR RI tahun 2001 serta penerbitan Maklumat Presiden 23 Juli 2001,

i1Pendapat ini dikutip dari tulisan Ignas Kleden. Ibid. Him:4.

12/bid. HIm. 5

${ }^{13}$ Majalah Forum Keadilan. No. 18, 5 Agustus 2001.

${ }^{14}$ Moh. Mahfud MD. "Sl Alami Problem Konstitusi". Harian Jawa Pos RadarJogja. Minggu. Tanggal 22 Juli 2001. 
menurut MPR tindakan Presiden sungguhsungguh melanggar haluan negara. Dan oleh karenanya melalui Ketetapan MPR No. II/MPR 2001, MPR memberhentikan K.H. Abdurrahman Wahid sebagai Presiden RI dan mencabut serta menyatakan tidak berlaku lagi Ketetapan MPR RI No. VII/MPR/1999 tentang Pengangkatan Presiden RI.

Untuk ke depan, MPR harus mengkaji kembali, pertama, materi tentang pertanggungjawaban Presiden perlu diatur di dalam batang tubuh UUD. Kedua, penegasan apakah penjelasan UUD 1945 masih menjadi bagian tak terpisahkan dari Batang Tubuh UUD 1945 dan apakah masih berlaku. Ketiga, periu segera direalisir pembentukan mahkamah konstitusi yang nantinya akan dapat memecahkan kebuntuan konstitusi atau pun untuk pengujian terhadap peraturan perundang-undangan yang belakangan ini ditafsirkan sendiri-sendiri oleh Presiden maupun oleh DPR/MPR. Di samping itu, harus dipikirkan dari sekarang pembenahan secara serius dan komprehensif materi apa saja yang harus masuk ke dalam konstitusi Indonesia supaya menjadi konstitusi yang ideal dan mempunyai jangkauan ke depan, sehingga berbagai permasalahan kenegaraan dapat ditemukan solusinya melalui konstitusi tersebut:

\section{Maklumat Presiden}

Sejak negara diproklamasikan sampai kini keadaan bahaya darurat itu sering dialami negara dan pemerintah, baik seluruh wilayah negara maupun sebagian dari daerahnya. Sampai tiba saatnya Presiden menyatakan Dekrit Presiden 5 Juli 1959, hukum negara darurat telah diatur dalam berbagai perundangundangan, seperti UU Keadaan Bahaya No. 6 Tahun 1946, UU No. 74 Tahun 1957 dan beberapa materi Regeling SOB Stb. 1939 No. 582. Baru setelah kembali ke UUD 1945, tanggal 16. Desember 1959 disusunlah Peraturan Pemerintah Pengganti Undang-undang (Perpu) tentang Bahaya dalam Perpu No. 23 Tahun 1959.

Pengaturan keadaan darurat negara secara tegas telah disebutkan di dalam UUD 1945 Pasal 12: "Presiden menyatakan keadaan bahaya, syarat-syarat dan akibat keadaan bahaya ditetapkan dengan Undang-undang." Pasal 12 inimenghendaki adanya UU tentang Syarat dan Akibat Keadaan Bahaya. Pembuat UUD 1945 memandang arti penting dan bahaya dari suatu keadaan yang dinyatakan bahaya, oleh karena itu ada pembatasan wewenang kepada Presiden tentang kapan Presiden dibenarkan menyatakan keadaan bahaya. Dan sekaligus ditetapkan perubahan ketatanegaraan sebagai akibat pernyataan keadaan bahaya. ${ }^{15}$ Di samping ketentuan dalam Pasal 12 tersebut, Pasal 22 ayat (1) mengatur dalam hal ikhwal "kegentingan" yang memaksa Presiden "berhak" menetapkan Peraturan Pemerintah Sebagai Pengganti Undang-undang (Perpu). Melalui kedua pasal di dalam UUD 1945 tersebut Presiden secara tegas diberi kekuasaan untuk mengantisipasi

${ }^{15}$ Suwoto Mulyosudarmo. "UU tentang KKN dalam Perspektif Hukum Tata Negara". dalam Ignatius Haryanto. 1999. Kejahatan Negara, Telaah tentang Penerapan Delik Keamanan Negara. Jakarta: ELSAM. Him. $x$. 
suatu keadaan bahaya atau darurat di dalam wilayah kekuasaannya.

Ketentuan di dalam Pasal 22 ayat (1) mengisyaratkan apabila keadaannya lebih genting dan amat terpaksa dan memaksa, tanpa menunggu adanya syarat-syarat yang ditentukan lebih dahulu oleh dan dalam suatu undang-undang, serta bagaimana akibatakibat yang tidak sempat ditunggu dan ditetapkan dalam suatu undang-undang Presiden berhak menetapkan Perpu sekaligus menyatakan suatu keadaan bahaya atau darurat. Pernyataan ini dipandang lebih memiliki kepastian hukum jika dibandingkan dengan penerapan keadaan darurat yang tidak tegas misalnya penerapan DOM di Aceh dan lain sebagainya. Prinsip penerapan keadaan bahaya tidak boleh berlama-lama. Hukum darurat diadakan untuk secepatnya menghapuskan bahaya itu kembali ke keadaan damai, aman dan normal. ${ }^{16}$ Fungsi utama hukum negara darurat (Staatsnoodrecht) ialah menghapuskan segera bahaya itu sehingga kembali normal. Berlawanan dengan itu, misalnya berlamalama Nood (bahaya) itu menyalahi tujuan diadakan hukum negara darurat. Keadaan bahaya dengan upaya luar biasa harus ada keseimbangan, supaya kewenangan itu tidak berkelebihan untuk mencegah penyalahgunaan kekuasaan yang besar.
Namun harus pula dipertimbangkan, bagaimana supaya dalam keadaan bahaya (Staatsnoodrecht) hak-hak asasi manusia tetap dihargai secara patut sebagaimana layaknya. Demikian pula terhadap UUD dan hukum lain, tidak dihapuskan seluruhnya, melainkan hanya dalam waktu singkat dan sementara saja dan bukan untuk selamanya. ${ }^{17}$

Keadaan bahaya itu adalah sesuatu yang abnormal, untuk mengatasi bahaya itu hukumnya pun dalam keadaan biasa pun harus dipandang abnormal dan luar biasa, mungkin dalam keadaan normal tindakan penguasa itu masuk dalam kategori onrechtmatig, namun karena keadaan bahaya atau abnormal, maka tindakan penguasa itu adalah sah dan dapat dibenarkan. ${ }^{18}$. Fungsi utama hukum negara darurat ialah menghapuskan segala bahaya itu sehingga kembali normal. Keadaan darurat dengan upaya luar biasa harus ada keseimbangan, supaya kewenangan itu tidak berkelebihan untuk mencegah penyalahgunaan kekuasaan yang besar. Harus pula dipertimbangkan, bagaimana supaya dalam keadaan darurat (staatsnoodrecht) hak-hak asasi manusia tetap dihargai secara patut dan terhadap UUD atau pun hukum lain tidak dihapuskan seluruhnya, melainkan hanya dalam waktu singkat dan sementara saja dan bukan untuk selamanya. ${ }^{19}$

${ }^{18}$ Herman Sihombing. 1996. Hukum Tata Negara Darurat di Indonesia. Jakarta: Djambatan. Hlm. viii. Lihat dalam Ni'matul Huda. 1999. Hukum Tata Negara: Kajian Teoritis dan Yuridis Terhadap Konstitusi Indonesia. Yogyakarta: Pusat Studi Hukum FH UIl bekerjasama dengan Gama Media. HIm. 65. ${ }^{17}$ A.A.L.F. Van Dullemen. "Staatsnoodrecht en Democratie". 1947. Dikutip kembali oleh Herman Sihombing. Ibid. HIm. 7.

${ }^{18}$ Ibid. HIm. 5.

${ }^{19} \mathrm{lbid}$. 
Untuk dapat mengklasifikasi hukum negara daruràt sëbagai hukum yang sah harus memenuhi syarat-syarat sebagai berikut: (1) harus menjadi nyata, bahwa kepentingan negara tertinggi (hoogste staatsbelang) menjadi tariuhan (staat op het spel) dan tergantung dari tindakan yang bersangkutan, apakah negara ini langsung hidup atau tidak; (2) bahwa - tindakan ini betul-betul perlí dilakukan dan tidak cukuplati suatu tindakan yang kurang daripada itu; (3) tindakan-tindakan tersebut sementara sifatnya; (4) bahwa waktu tindakan diambil, DPR tidak dapat mengadakan sidang atau rapatnya secara nyata dan sungguh.. ${ }^{20}$

Di dalam Perpu No. 23 Tahun 1959 jo UU No. 52/Prp/1960 jo UU No. 1 Tahun 1961 keadaan bahaya dibedakan dalam tiga tingkatan keadaan, yaitu (a) darurat sipil; (b) darurat militer; (c) darurat perang. Di dalam Pasal 1 ayat (1)-nya disebutkan Presiden/ Panglima Tertinggi Angkatan Perang menyatakan seluruh atau sebagian dari wilayah Negara Republik Indonesia dalam keadaan bahaya dengan tingkatan keadaan darurat sipil atau keadaan darurat militer atau keadaan darurat perang, apabila: 1) keamanan atau ketertiban hukum di seluruh wilayah atau di sebagian wilayah Negàra Republik Indonesia terancam oleh pemberontakan, kerusuhan-kerusuhan, atau akibat bencana alam, sehingga dikhawatirkan tidak dapat di atasi oleh alat-alat perlengkapan secara biasa; 2) timbul perang atau bahaya perang atau dikhawatirkan perkosaan wilayah Negara Republik Indonesia dengan cara apa pun juga; 3) hidup Negara berada dalam keadaan bahaya atau dari keadaan-keadaan khusus ternyata ada atau dikhawatirkan ada gejalagejala yang dapat membahayakan hidup Negara. Di dalam ayat (2) dinyatakan bahwa penghapusan keadaan bahaya dilakukan oleh Presiden/Panglima Tertinggi Angkatan Perang.

Seiring dengan semakin intensifnya gerakan masyarakat (mahasiswa) menjelang Sidang Umum MPR 1999 yang dikhawatirkan akan menimbulkan kerusuhan di tanah air, pemerintah nampaknya telah mentargetkan RUU Keselamatan dan Keamanan Negara (KKN) bisa selesai dibahas dan diterima oleh DPR menjadi UU secepatnya. Tetapi ternyata RUU KKN banyak ditolak oleh berbagai elemen masyarakat, kemudian setelah dilakukan sedikit penyempurnaan judul RUU. tersebut diubah menjadi RUU Penanggulangan Keadaan Bahaya (PKB).

$\downarrow$ UU PKB telah ditolak oleh sebagian masyarakat karena mereka menaruh kecurigaan yang sangat besar, bahwa UU tersebut akan dipakai sebagai alat penekan Pemerintah terhadap aktivitas/tindakan masyarakat yang secara politis bersebrangan dengan kekuasaan. Masyarakat merekam segala kejadian yang traumatis akibat perlakuan militer yang represif dan kurang bersahabat di masa Orde Baru, sehingga apa pun yang dilakukan oleh militer seolah harus ditolak. Kita tentu tidak menginginkan gambaran buruk itu terus muncul dalam benak rakyat Indonesia. Hal inilah salah satu alasan kenapa peran militer dalam segenap kehidupan berbangsa dan bernegara di Indonesia perlu ditinjau kembali. Pada sisi lain, penolakan sebagian masyarakat

${ }^{20}$ Oemar Seno Adji. 1985. Peradilan Bebas Negara Hukum. Cetakan Kedua. Jakarta: Erlangga. HIm. 53. 
terhadap RUU PKB besar kemungkinan karena kurangnya sosialisasi materi muatan UU tersebut kepada.masyarakat.

Mengapa UU PKB ditentang masyarakat, sementara 'pada sisi lain Anggota DPR menyetujuinya? Keselamatan siapa sesungguhnya yang harus dilindungi? Pertanyaan semacam itu menjadi relevan dikedepankan karena melalui UU .PKB masyarakat menilai telah terjadi pembelahan posisi sipil dan militer untuk kepentingan keselamatan negara. Seolah-olah yang punya hak dan kewajiban untuk menanggulangi dan menjaga keselamatan negara hanya militer, dan rakyat diposisikan sebagai pihak yang akan mengancam/membahayakan keselamatan negara. Nampaknya, ancaman itu telah ditujukan pada kelompok-kelompok masyarakat yang melakukan tindakan penentangan terhadap penguasa dan bukan ancaman dari negara lain.

Dengan disetujuinya RUU PKB menjadi UU PKB oleh DPR, sementara beberapa kalangan masyarakat, partai politik serta LSM di luar gedung DPR meneriakkan penolakan terhadap UU tersebut - bahkan telah jatuh korban di pihak masyarakat maupun aparatsudah cukup bukti bahwa Anggota DPR yang seharusnya mendengarkan aspirasi masyarakat ternyata telah mengabaikan șuara nurani rakyat, yang didengar justru suara pemerintah dan dirinya sendiri. Itulah cermin hati nurani wakil rakyat yang selama 32 tahun ini mendominasi wajah demokrasi Indonesia. Mereka yang mengaku sebagai wakil.rakyat nampaknya belum paham betul apa yang seharusnya mereka lakukan di era reformasi ini. Sebagian besar dari wakil rakyat masih terkungkung pada doktrin Orde Baru uang menempatkan wakil rakyat sebagai tukang stempel atas segala keinginan dan kepentingan penguasa. Sikap Anggota DPR yang menyetujuj RUU PKB menjadi UU PKB telah melukai kepercayaan dan amanat kedaulatan rakyat yang telah diberikan oleh mereka melalui Pemilu.

Oleh karenà UU PKB dalam kenyataan banyak mendapat tentangan (penolakan) dari masyarakat luas, maka pemerintah ketika itu. (Presiden B.J. Habibie) menunda pemberlakuan UU tersebut, dan sampai habis masa jabatannya Presiden B.J. Habibie belum juga mengundangkan UU PKB. Begitu pula ketika telah terjadi pergantian jabatan Presiden, Presiden Abdurrahman Wahid sampai hari ini belum juga mengundangkan UU PKB yang sudah disetujui DPR tanggal 23 September 1999, bahkan akan menunda pengundangannya sampai Januari 2001. Ternyata sampai hari ini UU tersebut belum juga disahkan oleh Presiden. Inilah UU yang 'terlunta-lunta' nasibnya, bahkan sudah melampaui tiga kali pergantian Presiden.

Sampai pada akhirnya. Presiden Abdurrahman Wahid mengeluarkan Maklumat Presiden tanggal 23- Juli 2001, yang menimbulkan sikap pro dan kontra di masyarakat. Dasar pijakan yuridis yang dipakai untuk memberlakukan keadaan darurat adalah. UU No. 23/Prp/1959, karena UU PKB belum sah berlaku sehingga pemberlakuan. Maklumat tersebut tidak perlu adanya persetujuan dari. DPR (sebagaimanà yang diatur dalam UU PKB). Mak'lumät Presiden dikeluarkan karena adanya 'Krisis' yang berkepanjangan dan hubungan kelembagaan antara Presiden dan DPR menemui jalan buntu, jalan kompromi juga sudah tertutup. Maklumat. Presiden bunyi selengkapnya, sebagai, berikut: . 


\section{Maklumat Presiden RI}

Setelah melihat dan memperhatikan dengan seksama perkembangan politik yang menuju pada kebuntuan politik akibat krisis konstitusional yang berlarut-larut yang telah memperparah krisis ekonomi dan menghalangi usaha penegakan hukum dan pemberantasan korupsi yang disebabkan oleh pertikaian kepentingan politik kekuasaan yang tidak mengindahkan lagi kaidah-kaidah perundangundangan.

Apabila ini tidak dicegah, akan segera menghancurkan berdirinya Negara Kesatuan Republik Indonesia, maka dengan keyakinan dan tanggung jawab untuk menyelamatkan negara dan bangsa serta berdasarkan kehendak sebagian terbesar masyarakat Indonesia, kami selaku Kepala Negara Republik Indonesia terpaksa mengambillangkah-langkah luar biasa dengan memaklumkan:

1. Membekukan Majelis Permusyawaratan Rakyat Republik Indonesia dan Dewan Perwakilan Rakyat Republik Indonesia.

2. Mengembalikan kedaulatan ke tangan rakyat dan mengambil tindakan serta menyusun badan yang diperlukan untuk menyelenggarakan pemilihan umum dalam waktu satu tahun.

3. Menyelamatkan gerakan reformasi total dari hambatan unsur-unsur Orde Baru, dengan membekukan Partai Golkar sambil menunggu keputusan Mahkamah Agung.

Untuk itu, kami memerintahkan seluruh jajaran TNI dan Polri untuk mengamankan langkah-langkah penyelamatan NegaraKesatuan Republik Indonesia dan menyerukan kepada seluruh rakyat Indonesia untuk tetap tenang sertamenjalankan kehidupan sosial ekonomi seperti biasa. Semoga Tuhan Yang Maha Kuasa meridloi negara dan bangsa Indonesia.

Jakarta, 22 Juli 2001

Presiden Republik Indonesial

Panglima Tertinggi Angkatan Perang

KH. Abdurrahman Wahid
Maklumat Presiden 23 Juli 2001 apabila dikaji dari aspek yuridis materi muatannya tentu akan bertentangan dengan konstitusi yang berlaku, karena hakekat pemberlakuan keadaan darurat adalah untuk antisipasi cepat atas keadaan di masyarakat, maka hukumnya pun tidak normal. Di samping itu, TNI dan Polri yang diperintahkan untuk melaksanakan Maklumat tersebut tidak mendukung Maklumat Presiden, realitas politik di parlemen juga tidak mendukungnya. Sehingga maklumat tersebut tidak bisa djjalankan secara efektif di masyarakat.

Maklumat Presiden 23 Juli 2001 jelas akan bertentangan dengan konstitusi, karena prasyarat untuk dapat diberlakukannya keadaan darurat sebagaimana yang diatur dalam UU No. 23 Tahun 1959 belum terpenuhi. Dengan kata lain, meskipun UUD 1945 memberikan kewenangan kepada Presiden untuk menyatakan keadaan darurat, tetapi penerapannya hanus benar-benar dapat terukur supaya tidak menimbulkan kesan adanya penyelewengan kekuasaan dari Presiden. "Keadaan darurat" jangan hanya menjadi otoritas diri seseorang dalam menafsirkannya, tetapi paling tidak harus mendekati senyatanya keadaan dalam masyarakat.

Berdasarkan kajian yang dilakukan oleh berbagai kalangan dan juga fatwa Mahkamah Agung terhadap Maklumat Presiden 23 Juli 2001, menyimpulkan bahwa Maklumat Presiden sangat lemah posisinya dari perspektif yuridis. Pertama, membekukan Majelis Permusyawaratan Rakyat Republik Indonesia. dan Dewan Perwakilan Rakyat Republik Indonesia bukanlah wewenangan Presiden. UUD 1945 tidak memberikan kewenangan yang sejauh itu kepada Presiden. Kedua, menyelenggarakan pemilihan umum yang 
dipercepat dalam tempo satu tahun, bukanlah menjadi wewenang Presiden, karena yang bisa menentukan percepatan pemilu adalah MPR. Sebagaimana yang pernah terjadi pada periode kepemimpinan Presiden B.J. Habibie tahun 1999. Ketiga; membekukan Partai Golkar sambil menunggu keputusan Mahkamah Agung, dipandang sebagai bentuk intervensi Presiden pada proses peradilan. Karena menurut UU No. 2 Tahun 1999 tentang Partai Politik yang boleh membekukan partai adalah MA setelah ada putusan pengadilan yang punya kekuatan hukum. Sementara, kasus Golkar saat Maklumat dikeluarkan tengah disidangkan oleh MA.

Di samping itu, realitas politik di MPR menolak Maklumat tersebut. Dari 601 Anggota MPR yang hadir, 599 menyatakan menolak dan dua Anggota abstain. Pada pengambilan suara tersebut, seluruh anggota Fraksi TNII Polri menyatakan menolak Maklumat. Sikap MPR terhadap Maklumat Presiden 23 'Juli 2001 kemudian dikukuhkan dalam Ketetapan MPR RI No. I/MPR/2001 dengan menyatakan Maklumat Presiden RI 23 Juli 2001adalah tidak sah karena bertentangan dengan hukum dan tidak mempunyai kekuatan hukum. Hal ini berbeda dengan Dekrit yang pernah dikeluarkan oleh Presiden Soekarno 5 Juli 1959. Mayoritas anggota parlemen dan militer mendukung dikeluarkannya dekrit, meskipun belakangan dengan dekrit tersebut kekuasaan Soekarno menjadi luar biasa besar (diktator) dengan demokrasi terpimpinnya.

Peristiwa ketatanegaraan yang berlangsung akhir-akhir ini memberikan banyak pelajaran dan hikmah bagi seluruh rakyat dalam berbangsa dan bernegara. Paling tidak semua menjadi sadar, betapa konstitusi (UUD 1945) perlu dirombak total atau diganti yang baru. Supaya masing-masing penyelenggara negara ada pedoman yang pasti dalam bertindak, agar di masa datang tidak terulang perdebatan yang melelahkan antara lembaga-lembaga tinggi negara atau pun lembaga tertinggi negara, di mana masing-masing mendailikan sebagai pihak yang 'paling benar' dan yang lain adalah salah. Masih banyak pekerjaan yang harus segera dirampungkan.

\section{Daftar Pustaka}

Adji, Oemar Seno. 1985. Peradilan Bebas Negara Hukum. Cet. Kedua. Jakarta: Erlangga.

Asshiddiqie, Jimly. "Pemberhentian Presiden Melalui Sidang Istimewa yang Dipercepat", Makalah yang dipresentasikan di depan Fraksi PDIP di Jakarta, tanpa tanggal dan tahun.

Haryanto, Ignatius. 1999. Kejahatan Negara. Jakarta: ELSAM.

Huda, Ni'matul. 1999. Hukum Tata Negara Kajian Teoritis dan Yuridis Terhadap Konstitusi Indonesia. Yogyakarta: Pusat Studi Hukum Fakultas Hukum UII - Gama Media.

Kusnardi dan Hermaily Ibrahim. 1988. Pengantar Hukum Tata Negara Indonesia. Jakarta: Penerbit Pusat Studi Hukum FH U!.

Sihombing,Herman. 1996. Hukum Tata Negara Darurat di Indonesia. Jakarta: Djambatan. 
Simorangkir, J.C.T. 1985. Penetapan UUD Ketetapan MPR No. Ill/MPR/1978. Dilihat Dari Segi Hukum Tata Negara Ketetapan MPR No. II/MPR/1999. Indonesia. Jakarta: Gunung Agung.

Majalah Forum Keadilan. No. 18, 5 Agustus 2001.

Ketetapan MPR No. II/MPR/2000.

Ketetapan MPR No. III/MPR/2000.

Harian Jawa Pos Radar Jogja. Tanggal 22 Juli 2001.

Harian Kompas. Tanggal 30 Juli 2001

Ketetapan MPRS No. XX/MPRS/1966.

Ketetapan MPR No. VI/MPR/2000.

Ketetapan MPR No. VII/MPR/2000.

Ketetapan MPR No. I/MPR/2001.

Ketetapan MPR No. II/MPR/2001.

Maklumat Presiden 23 Juli 2001

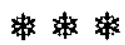

